University for Business and Technology in Kosovo

UBT Knowledge Center

UBT International Conference

2016 UBT International Conference

Oct 28th, 9:00 AM - Oct 30th, 5:00 PM

\title{
Antonyms and synonyms in relation to the Buildings Performance
}

\author{
Binak Beqaj \\ University for Business and Technology, bbeqaj@ubt-uni.net \\ Blerta Vula Rizvanolli \\ University for Business and Technology, blerta.vula@ubt-uni.net \\ Gent Hasimja \\ University for Business and Technology, gent.hasimja@ubt-uni.net
}

Follow this and additional works at: https://knowledgecenter.ubt-uni.net/conference

Part of the Architecture Commons

\section{Recommended Citation}

Beqaj, Binak; Rizvanolli, Blerta Vula; and Hasimja, Gent, "Antonyms and synonyms in relation to the Buildings Performance" (2016). UBT International Conference. 77.

https://knowledgecenter.ubt-uni.net/conference/2016/all-events/77

This Event is brought to you for free and open access by the Publication and Journals at UBT Knowledge Center. It has been accepted for inclusion in UBT International Conference by an authorized administrator of UBT Knowledge Center. For more information, please contact knowledge.center@ubt-uni.net. 


\title{
Antonyms and synonyms in relation to the Buildings Performance
}

\author{
Binak Beqaj $^{1}$, Blerta Vula Rizvanolli², Gent Hasimja ${ }^{3}$ \\ ${ }^{1,2,3}$ UBT - Higher Education Institution, Lagjja Kalabria, 10000 p.n., \\ Prishtine, Kosovo \\ [bbeqaj $^{1}$, blerta.vula ${ }^{2}$, gent.hasimja $\left.{ }^{3}\right\} @$ ubt-uni.net
}

\begin{abstract}
The facade is a representative element of a building which may faces the roads or public spaces. It is essential that the façade is correctly built because it directly influences the performance of the building:

\section{Energy Performance + Space Performance + Aesthetical Performance $=$ Successful Building}

These performances are closely related to facades characteristics, because facades construction has a direct influence in monthly charges for heating, cooling, ventilation while they indirectly influence the lighting loads. This impact, determine the energy use of the building and the comfort of its internal functioning. Synonyms such as Material, Color, Appearance and Displayand Antonyms such as Realism, Character and Individualityaffect the building classification as Successful Building which addresses the essential objective of providing tools and new technologies in the decision making process since the early designing a building.
\end{abstract}

Keywords: facade, performance, power, space, aesthetics, public convenience, technology

\section{Introduction}

During the building's construction the most important thing is to understand the construction process and the compatibility of the design with construction codes and regulations, assuming to fulfill the basic requirements in building's function, installation, materialization or external appearance. It is essential for a building to interrelate with its urban surroundings realized based on the special plans made by responsible institutions:

- Construction should contribute in protecting fundamental rights for life and work in the building

- Construction should insure that the final outcome for a healthy and sustainable environment

- Construction should harmonize the building aesthetics with its function and comfort

In order to obtain the best performance of the building, during the process, it should be treated in the function of the respective clients to which it is dedicated, should be consistent with the available resources and should be subject to continuous control and supervision. This can be achieved with the involvement of two main factors: advanced construction industry, mainly in terms of achieving the performance energy and construction legal framework - policies through codes and standards.

Successful performance of the building is assessed by parameters that are related to urban/architectural design and the main focus is on the facades and their role in their role of 
Book of Proceedings

International Conference on Architecture and Spatial Planning

impacting the building in operational terms. Facades can directly affect cost savings through energy efficiency settings as well as they contribute in determining building identity. Building performance is closely related to integrated models of its design and construction under the "Design-Bid-Build" system. The building performance objective should be based on "Challenges 2030" considering their challenges, energy performance codes, construction industry strategies, etc.

Based on the research conducted in Pristina (through citizens-surveys, July 2016), the following components have been identified as the most responsible factors that influence the energy performance of the buildings (Fig.1)

Responsible factors for building performance

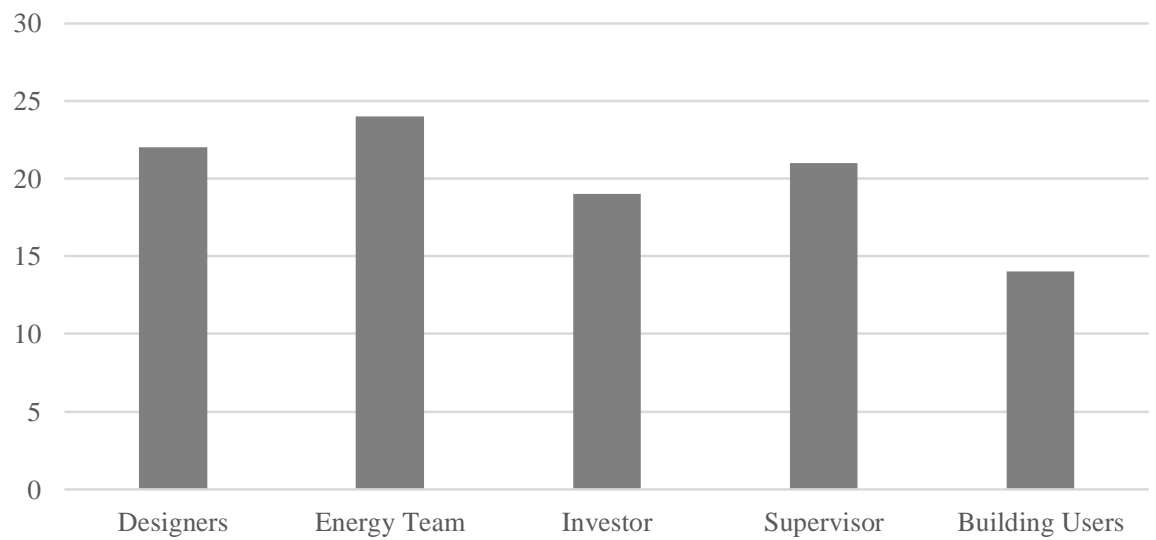

Fig.1. Responsible factors that influence building performance (source: research, July 2016)

From the above mentioned research, it is indicated that the building occupants and supervisors are responsible for building maintenance and energy condition upgrade while the designers shall take care during the planning phase, to accommodate the building commodity internally - in its interior and externally - in its facade. Finally the building's owner is responsible to ensure rational usage of building commodities based on inhabitant requirements.

\section{Elements that shape successful buildings}

Construction is characterized with its dynamic and complex nature that integrates many stakeholders with interdependent and integrated objectives and interests. Nevertheless, all of them have different objectives that relate to their interest for the building success.

According to Atkinson (1999), based on the managerial perspective, the Iron Triangle - TimeCost-Money is an excellent tool that would insure project success. While Chan and Chan (2004) explain that for construction industry, project success means more than that, because it has to include building users and take care for their satisfaction. Moreover, they emphasize that project success involve, health and safety measures during construction phase, stakeholders satisfaction, environmental performance and building quality (Fig.2). 


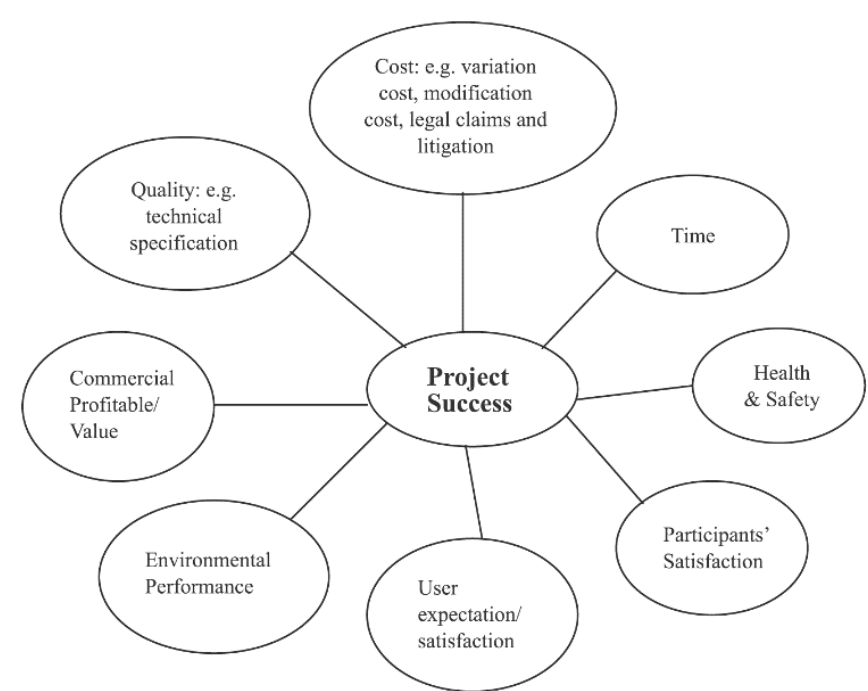

Fig.2. Building Construction Success Factors

Other authors such as: Alarcon and Ashley et al. (1987) have summarized construction success as: "Results much better than expected or normally observed in terms of cost, schedule, quality, safety, and participant satisfaction." While, a contrary opinion is expressed by Tuman (1986) who said "Success means having everything turn out as hoped. Anticipating all project requirements and have sufficient resources to meet needs in a timely manner."

Meanwhile, Energy oriented Success of a building would be defined as a combination of the following factors:

- Decision making

- Materialism

- $\underline{\text { Color }}$

- $\underline{\text { Technology }}$

Decision Making Process - The use of a multi-criteria decision analysis method is a way to help the decision maker to select the most suitable design alternative regarding the different aspects that affect the indoor environmental quality and the energy performance of the buildings (Majumder, 2015).

Substantial decision making elements are:
- Thermal Comfort,
- Acoustic Comfort,
- Indoor Air Quality.
- Visual Comfort,
- Energy Needs 
Book of Proceedings International Conference on Architecture and Spatial Planning

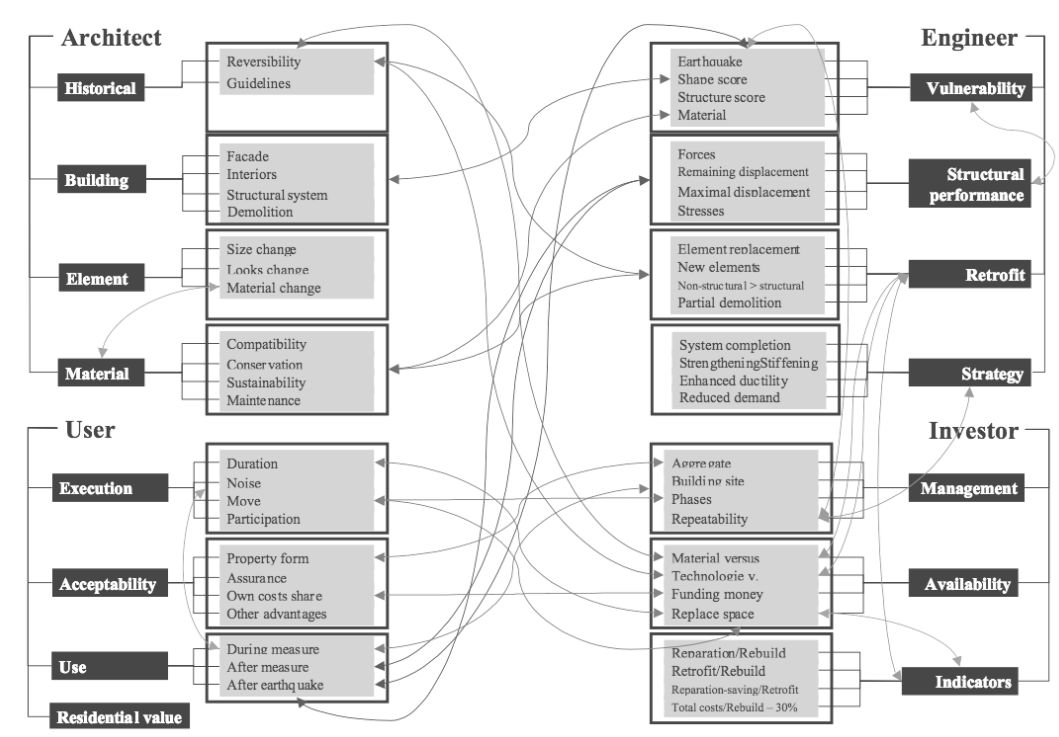

Fig.3. Decision making variances in a construction project

Facade Material - External plasters act as a barrier against negative external influences humidity, rainfall, temperature changes, UV radiation and chemical attack. They improve thermal insulation properties and the aesthetics of the building (Cole et al. 1992).

- Plastered facades - traditional multilayer plasters, thin-layer plasters, special plasters and noble plasters

- Masonry Facades - Clinker and Silica

- Dry Facades - Timber, Stone, Siding and Plastic

- Glued Facades - Clinker, Silica and Stone

- Modern Facades - Green Walls and Led Screen

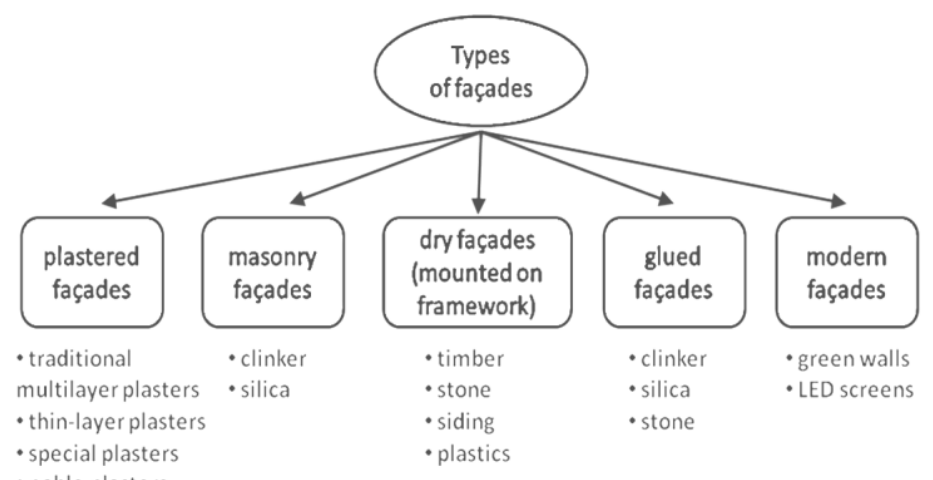

Fig.4. Façade material categories

Facade Color - can actually be used to "level out" emotions or to create different moods (Kurt and Osueke, 2014). They are used to control refection or absorbance of solar radiations in buildings. 
The use of highly reflective "cool" coatings helps maintain lower exterior surface temperatures of roofs and building facades and consequently contributes to increased indoor thermal comfort during the hot season, which reduces the need for cooling. This technique for improving thermal comfort inside buildings is low cost, effective, easy to apply, energy efficient and helps reduce the phenomenon of Urban Heat Island.
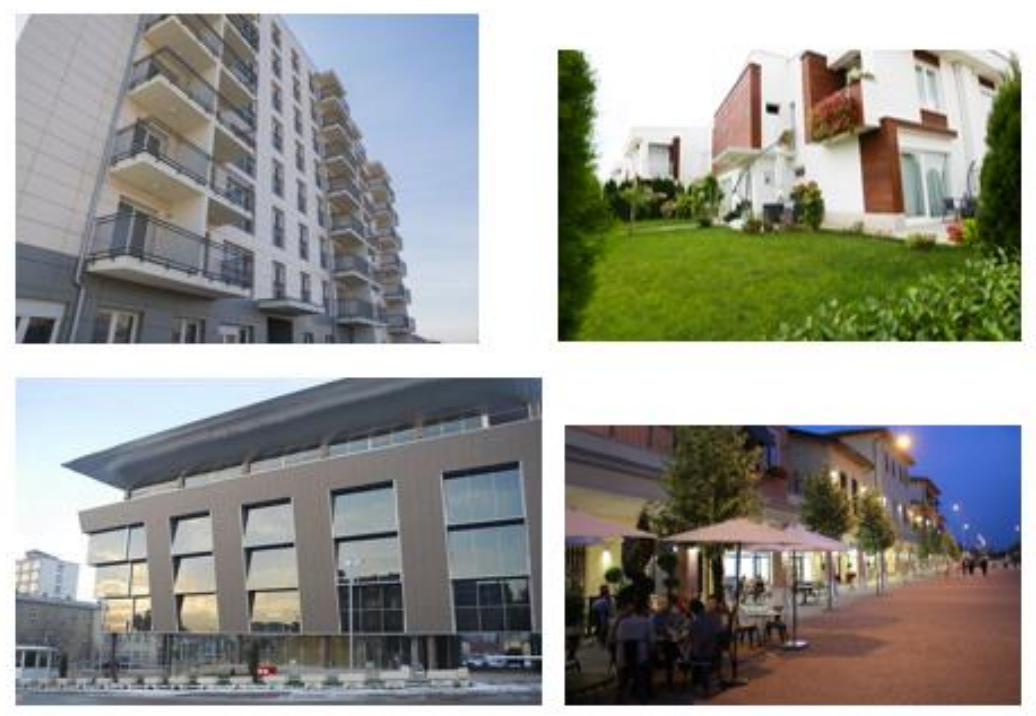

Fig.5. Façade forms and structures from different buildings

Facade Technology- advanced facade technology allows for reduced plant downsizing and energy saving. Ventilated double-skin facades reducing solar gains in summer and providing thermal insulation in winter is an example of a technology, which is become very common in building design (Kragh et al. 2002).

- Solar Control Facades

- Day-lighting Facades

- Double Skin and Natural Ventilated Facades

- Active Façade Systems

As it is emphasized above, façade play a substantial role on the energy performance of the building. Lately, Leśniak and Balicki (2016)tried to go further by identifying three main functions of the façade:

- Protection and shielding - it offers protection of the interior against unfavorable environmental factors. Today, the main purpose of the construction industry concerning façades is to improve such parameters as thermal transmittance, fire resistance and proper acoustics.

- Information - they should first of all enable the identification of the main functions of the facility and also cause feelings appropriate to that function. It can also indicate the time when the building was built.

- Aesthetics - because they play a representative role; they are a kind of the 'packaging', so that the building attracts the attention of potential buyers or tenants.

Considering the empirical review of the previous studies, it can be summarized that the building success is the best combination of Building Energy Performance, Space Performance and Aesthetical Performance 
Book of Proceedings International Conference on Architecture and Spatial Planning

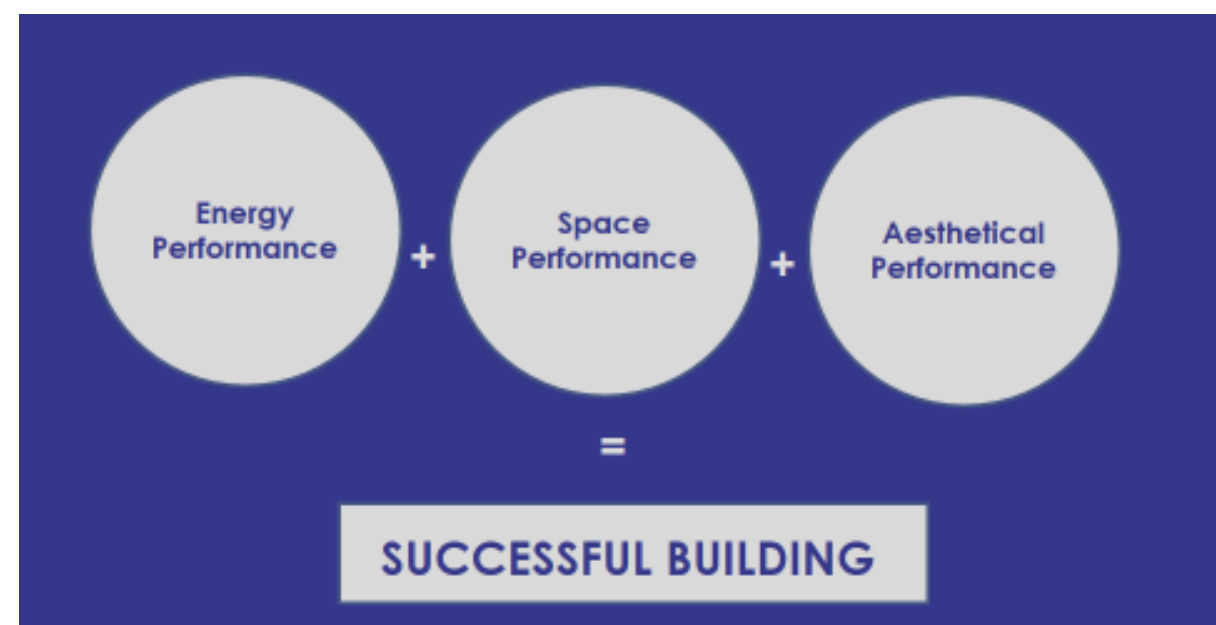

Fig.6. Building Success Factors

As it is presented in Fig.6, from three main factors which determines a successful building, two of them are interrelated with façade and its characteristics:

- Energy performance

- Aesthetical performance

In both cases, an important evaluation parameters with influence are building materials and building technologies.

\section{Conclusions and recommendations}

High performance building is based on its identity, character and development trends. Those parameters are influencing each other and not always they are well harmonized in the way that they affect positively systemic development and as result of that in many cases buildings do not have high performance, especially in countries under development such as Kosova is, and results from analyses shows that those buildings produce negative impacts not only in daily life of citizens but also around their urban environment too. This requires a detail analysis and further evaluations about general or specific indicators with negative influence on building performance:

- Lack of "feedback" from the previous building's performance;

- Lack of knowledge by operators on how systems are designed;

- Lack of mechanism to determine comprehensive building's performance;

- Lack of public recognition for building's performance;

- Lack of understanding of qualitative building's performance;

- Ignorance of building's performance environmental impacts;

- Building's performance impact on building costs, urban surrounding etc.

The answer on those raised issues, can be found on system approach towards problematic issues related to building facades and their impact, and this is not possible without:

- Institutional effectiveness through policy, laws and regulations

- Inclusiveness of all relevant partners in the process; experts, civic society, business etc.

- Feasibility studies and adequate budgeting for projects

- Partnerships between different stakeholders during design and construction process. 


\section{References}

1. Alarcon, L.F. and Ashley, D.B. (1996), "Modeling project performance for decision making”, Journal of Construction Engineering and Management, Vol. 1222 No. 3, pp. 265-73.

2. Atkinson, R. (1999). Project management: cost, time and quality, two best guesses and a phenomenon, its time to accept other success criteria. International journal of project management, 17(6), 337-342.

3. Chan, A. P., \& Chan, A. P. (2004). Key performance indicators for measuring construction success. Benchmarking: an international journal, 11(2), 203-221.

4. Cole, G. E., Holtgrave, D. R., \& Ríos, N. M. (1992). Internal and external factors that encourage or discourage health-relevant behaviors, 1-23.

5. Kragh, M., Colombari, M., \& Zobec, M. (2002). Advanced facades and HVAC systems: preliminary results of full-scale monitoring. Energy Efficient and Healthy Buildings in Sustainable Cities.

6. Kurt, S., \& Osueke, K. K. (2014). The effects of color on the moods of college students. SAGE Open, 4(1),

7. Leśniak, A., \& Balicki, J. (2016). Selection of façades finishing technology for commercial building using multi-criteria analysis. Entrepreneurial Business and Economics Review, 4(2), 67-79.

8. Majumder, M. (2015). Impact of urbanization on water shortage in face of climatic aberrations. Springer Verlag, Singapor.

9. Tuman, J. (1986). Success modeling: A technique for building a winning project team. In Proceedings of Project Management Institute (pp. 29-34). 